\title{
KITAP INCELEMESI
}

Bernard LEWİS, İnanç ve İktidar (Ortadoğu'da Din ve Siyaset) (Ankara, Ak1lçelen Kitaplar, 2017)

\section{Sadik KULA}

Doktora Adayı, Siyaset Bilimi ve Uluslararası İlişkiler Bölümü, Yıldız Teknik Üniversitesi

\section{Bu kitap değerlendirmesine atıf için}

Kula, Sadık, Kitap Değerlendirmesi: "Bernard Lewis, İnanç ve İktidar (Ortadoğu'da Din ve Siyaset), Ankara, Akılçelen Kitaplar, 2017", Uluslararası İlişkiler, Cilt 16, Sayı 61, 2019, s. 145-147, DOI: $10.33458 /$ uidergisi.541545

Erişim İçin: https://dx.doi.org/10.33458/uidergisi.541545

Bu makalenin tüm hakları Uluslararası İlişkiler Konseyi Derneği’ne aittir. Önceden yazılı izin almadan hiçbir iletişim, kopyalama ya da yayın sistemi kullanılarak yeniden yayımlanamaz, çoğaltılamaz, dağıtılamaz, satılamaz veya herhangi bir şekilde kamunun ücretli/ücretsiz kullanımına sunulamaz. Akademik amaçlı alıntılar bu kuralın dışındadır. Yazıda belirtilen fikirler yalnızca yazarına/yazarlarına aittir. UİK Derneğini, editörleri ve diğer yazarları bağlamaz. 


\title{
İnanç ve İktidar (Ortadoğu’da Din ve Siyaset)
}

\author{
Bernard LEWIS
}

Ayşe Mine ŞENGEL (Çev.), Akılçelen Kitaplar, Ankara, 2017, 235 sayfa, ISBN: 978-605-9800-50-1.

\begin{abstract}
Sadık KULA
Doktora Öğrencisi, Siyaset Bilimi ve Uluslararası İlişkiler Bölümü, İIBF, Yıldız Teknik Üniversitesi, İstanbul.

E-posta: kulasadik@yahoo.com
\end{abstract}

Bernard Lewis; bir Ortadoğu uzmanı olarak bölgeyi çok iyi bilen ve bölge hakkında derin tahliller yapan, aynı zamanda eski bir askerî istihbaratçı olarak, Amerika'nın Ortadoğu ile ilgili politikalarını belirleyen ve yönlendiren önemli isimlerden biridir.

Yazar; bazıları daha önce İngilizce dilinde yayınlanmamış makalelerinin ve yaptığı konuşmaların da bir derlemesini içeren, 2010 yılında Oxford University Press Inc. tarafından yayımlanan ve 2017 yılında Türkçe olarak basılan İnanç ve İktidar adlı eserinde Ortadoğu'yu Din ve Siyaset ekseninde yorumlamıştır. Kitap, önsöz ve bibliyografik ek bölümü haricinde, makale ve derlemelerinden oluşan toplam on üç bölümden müteşekkildir. Yazar, inançlar bağlamında Orta Doğu'nun güncel sorunlarının yanı sıra, inanç ve iktidar arasındaki ilişkiye yoğunlaşarak, İslam ve Orta Doğu'da demokrasi kavramına yeni bir bakış açısı getirmeye çalışmıştır.

Kitabında ağırlıklı olarak; Ortadoğu’nun siyasi ve hukuki gelenekleri, Müslümanların Hıristiyanlarla ve Musevilerle ilişkileri, eşitlik, özgürlük, adalet gibi kavramların yanında inanç, radikal hareketler, terörizm, diktatörlükler ve demokrasiden bahsetmektedir. Kitapta özellikle akademik ve politik çevrelerde sıkça tartışılan konular olan İslam ve demokrasi, İslam ile Batı (ya da Lewis'in söylediği gibi Hıristiyan âlemi) Yahudilik, cinsiyet meseleleri ve özgürlük ve adalet arasındaki ilişkiyi de içeren Ortadoğu siyasetinin ve dininin bir panoraması verilmektedir.

Kitabın ilk cümlelerinde "Sezar'ın hakkını Sezar’a, Tanrı'nın hakkını Tanrıya" (Matta 22:21) yer alan İncil'in buyruğu -Hıristiyanlık ile İslam arasındaki temel farklılı̆̆ın, özellikle kilise ve devlet ayrımının anlaşılması maksadıyla- derlemelerinin bir çok yerinde tekrar edilmektedir. Lewis, inanç ve iktidar konusuna çoğunlukla İslam ve Hıristiyanlık eksenli değinmiş ancak mantıklı bir çerçeve dâhilinde, Yahudiliğe yaklaşmak için de çeşitli argümanları kullanmıştır.

Lewis'in birçok bölümde değindiği ana argümanlardan birisi, İslam’ın sadece kişisel kimliğin değil, aynı zamanda Müslümanların birbirine ve devlete karşı olan sadakatinin ve otoritenin de temeli olduğunu iddia etmektedir. Bu bağlamda, dinin Müslümanların kimlik, sadakat ve otorite kazandıkları tek bir kimlik olabileceği çıkarımında bulunur. Orta Doğu'da demokratik bir sistemin önündeki engellerden birinin Batı olduğunu ifade eden yazar, İslam'ın temel metinlerinin hiçbir yerinde terörizm ve cinayetin emredilmediği şeklinde önemli bir değerlendirme de yapmaktadır. 
Lewis, Hıristiyanlık kurulduğunda, dini ve siyasi oluşumlarda her birinin içinde farklı yasalar ve kurumlar bulunan ve her biri farklı yaşam biçimlerini bildiren iki ayrı makam olmasının hilafına; İslam'ın oluşumu sırasında, dini ve siyasi otorite arasında bir ayırım yapılmamış olmasından bahsetmektedir. Dünyayı farklı uygarlıklara bölünmüş olarak gören yazar, Hıristiyanlık uygarlığına sık sık atıfta bulunmakta, ancak MS 313 yılında İmparator Konstantin tarafından getirilen "devletin dini olarak Hıristiyanlık” ibaresini de eleştirmektedir.

İnanç ve İktidar çalışmasının ana düşüncesi; tarihsel süreçlerde var olan İslam ile Hıristiyanlık arasındaki içsel karşıtlık olarak benimsenmiş görünmektedir. Lewis, İslam'ın başlangıcından bu yana, Müslümanlıkla Hıristiyanlık arasındaki ilişkiyi; kin ve rekabetten oluşan bir "medeniyetler çatışması" olarak belirtmektedir. "Ben Hıristiyanlık ile İslam arasındaki ilişki için çatışma sözcüğünü yeğliyorum.” (s.173) Ayrıca yazar, bölgede yaşayan Müslümanları kast ederek, "Ya onlara özgürlük getireceğiz ya da onlar bizi yok edecekler.” (s.187) diyerek bir şekilde İslam dişı uygarlıklara mensup topluluklara da uyarıda bulunmaktadır.

Kitapta Nazi Almanya’sı ve Komünist Rusya gibi, Ortadoğu diktatörlerinin de zulümlerini haklı göstermek için savaşa ihtiyacı olduğunu savunan yazara göre; barış, yalnızca onların diktasının çöküşü veya yenilgisi ile ortaya çıkabilecektir. Demokrasinin, halkların kalbine kolayca hâkim olabileceği, bölgede şans verilmiş olanlara ise ilham vereceği düşüncesinde olan yazar; İslam hukukunun Bay'a (Bağlılık Sözü) ve İstişare (Danışma) ilkelerini incelemiş ve demokrasinin Hıristiyanlıktan ziyade İslam’a daha yakın olduğu sonucuna ulaşmıştır.

Lewis, ilk defa 1950’li yıllarda Türkiye’ye yaptığı ziyarette eski Osmanlı İmparatorluğu'nun mirası olan cumhuriyetin İslam ile moderniteyi nasıl birleştirdiğini görerek, Müslüman devletler için laikliğin uzun vadeli tek uygulanabilir bir seçenek olduğu görüşünde olup, bu hususu kitabının birçok yerinde zikretmiştir. Ayrıca Türkiye için demokrasi konusunda yaşanan yapısal engeller hususunda "Uluslararası İslam Konferansını oluşturan kırk altı bağımsız devlet arasında sadece biri, Türkiye Cumhuriyeti, Batılı anlamda demokrasi olarak tanımlanabilir, ancak burada bile özgürlüğe giden yola engeller döşenmektedir." (s.61) şeklindeki kıymetlendirmesi de oldukça dikkate değer niteliktedir.

Yazar İslam'ı, aynı bölgede ve benzer etkiler etrafında kurulmuş olan Hıristiyanlı̆̆ın ve Yahudiliğin mirasçıları olarak görmektedir. İslam'ın genişlemesinin, Hıristiyan toprakların alınması pahasına olduğu ve Haçlı Seferlerini ise yalnızca Hristiyanlığın kaybettiği toprakları 'geri kazanma' girişimi olarak betimlemektedir.

İnanç ve İktidar kitabında aşırı basitleştirmenin veya sorunları basite indirgemenin birçok örneği bulunmaktadır. Bu çerçevede; Lewis'in en dikkat çekici değerlendirmelerinden biri; modern demokrasi ile Ortadoğu'da mevcut olan demokrasi anlayışı çerçevesinde, para ve iktidar ilişkisini tartışırken "Amerika'da para iktidarı satın almak için, Orta Doğu'daysa iktidar para edinmek için kullanılır." (s.75) demektedir. Yine "Bir ülke resmi adında demokratik sözcügünü kullanıyorsa bu bir tehlike işaretidir." (s.148) ibareleri gibi aşırı basitleştirmeler kabul edilebilir görünmekle beraber, bu gibi karmaşık sorunların geniş kapsamlı genellemelerinin sorunu doğru bir şekilde temsil etmeyeceği de aşikârdır.

Lewis'in kitabının en önemli eleştirilerinden biri de; Müslüman topluluğunun bir bütün olarak ele alınışından kaynaklanmaktadır. Bugün dünya çapında 63 Müslüman ülke ve 2 milyar civarındaki Müslümanla, her bir bireye uygulanacak tek bir sonuç çıkarmaya çalışmak ne derecede güvenilir 
bir varsayımdır. Lewis'in tüm Müslümanlara ait kişisel bir özdeşleştirme ile sadakat ve otorite duygularının dinden kaynaklandığını, bu sayede tutarlı bir İslam medeniyetinin var olduğunu kabul eden varsayımları kanaatimce kitabın zayıflıkları arasındadır.

Genel bir değerlendirme olarak, kitabın her bölümünde verilen temaların ve örneklerin birçoğu birbirinin içine geçmiş bir şekilde betimlendiğinden, çok tutarlı bir derleme olduğu söylenemez. Ayrıca bölümlerin ikisinde de aynı başlıkta "Avrupa ve İslam” anlatımı bulunmaktadır. Kitap dipnot ya da kaynakça içermemekte olup, bundan öte olarak Ortadoğu'da din ve siyaset bağlamında gerçekliği şüpheli bazı sonuçlar çıkarmakta ve İslam tarihi üzerine Avrupa merkezli ve geriye dönük bir bakış açısıyla yaklaşmaktadır. Bu kapsamda; kitabında yer alan iddialarını destekleyecek referans eksikliği söylemlerini daha da zayıflatmaktadır.

Kitabın bölümlerinin, son yirmi yıldan beri verilen konferanslar veya makalelerden oluşması neticesinde, geniş bir oranda tekrarlar mevcut olmasının yanında, kitabı baştan sona okuyan bir okuyucunun gerek konu gerekse içerik açısından tekrarlanan bir hoşnutsuzluk duygusu yaşaması mümkün olacaktır. Bu kapsamda Lewis'in tüm argümanlarını bulmak için kitabın ortalama olarak yarısını okumanın yeterli olabileceğini söylemek yanlış bir yorum olmayacaktır.

Bernard Lewis' in bazı İslami kavramları ve temaları analiz etme yaklaşımına yönelik eleştirilere rağmen, İnanç ve İktidar kitabının Ortadoğu'daki din ve siyasetin karmaşık ortamını teneffüs edebilmek açısından yararlı bir çalışma olduğunu da ifade etmek gerekir. Here, for instance, is Lewis contrasting political structures at home and abroad: "In America one uses money to buy power, while in the Middle East one uses power to acquire money." Even a subject as vexed as the search for ArabIsraeli peace boils down to this satisfyingly pithy formula: "If the conflict is about the size of Israel, then long and difficult negotiations can eventually resolve the problem. 